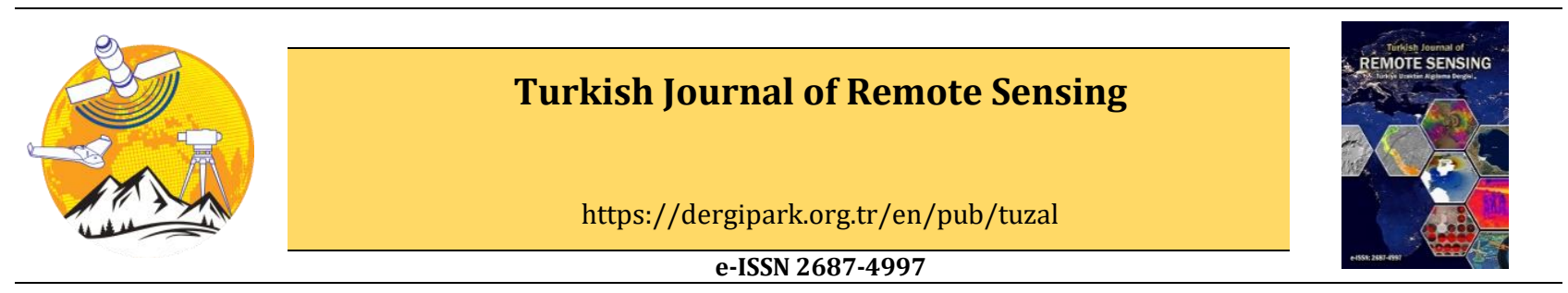

\title{
How do Sentinel-1 SAR images match with the existing maps
}

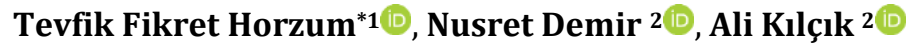 \\ ${ }^{1}$ Akdeniz University, Vocational School of Technical Sciences, Dep. of Architecture and Urban Planning, Antalya, Turkey \\ ${ }^{2}$ Akdeniz University, Faculty of Science, Department of Space Sciences and Technologies, Antalya, Turkey
}

Keywords

Remote Sensing

Sentinel-1(SAR)

OpenStreetMap(OSM)

Photogrammetric Digital Map (PDM)

\begin{abstract}
Synthetic Aperture Radar (SAR) images are used in several different applications for Remote Sensing purposes. SAR is an imaging sensor that can detect highresolution ground images under a wide variety of imaging conditions. As SAR is an active system, the data are already acquired with geo-position information. To investigate to verify the image spatial accuracy, a part of the Antalya region of Turkey was selected as test site. OpenStreetMap (OSM), SAR and Photogrammetric Digital Map (PDM) data within the test area were used. First, characteristic common points were selected on the OSM data and the SAR satellite image both. The projected coordinates of these points were calculated with the QGIS software. Normal distributions of the coordinate differences in these data sets were plotted. It was confirmed that the data sets were in normal distribution and standard deviation values were calculated. The maximum and minimum confidence interval (95\%) was determined according to the $2 *$ standard deviation limit values. $\mathrm{X}$ and $\mathrm{Y}$ coordinate differences were calculated for 49 selected points from both image pairs SAR\&OSM and SAR\&PDM. Finally, the maximum differences show that the SAR positional accuracy respect to OSM and PDM is below 1 pixel azimuthal resolution.
\end{abstract}

\section{Sentinel-1 SAR görüntüleri mevcut haritalarla nasıl eşleşir}

Anahtar Kelimeler:

Uzaktan Alglama

Sentinel-1(SAR)

OpenStreetMap(OSM)

FotogrametrikSayısal

Harita(FSH)

\begin{abstract}
ÖZ
Sentetik Açıklıklı Radar (SAR) görüntüleri, Uzaktan Algılama amacıyla birkaç farklı uygulamada kullanılır. SAR, çok çeşitli görüntüleme koşulları altında yüksek çözünürlüklü zemin görüntülerini algllayabilen bir görüntüleme sensörüdür. SAR aktif bir algılama sistemi olduğundan, veriler halihazırda coğrafi konum bilgisi ile elde edilmiștir. Görüntünün mekansal doğruluğunu araştırmak için, Türkiye'nin Antalya bölgesinin bir kısmı test bölgesi olarak seçildi. Test alanı içindeki OpenStreetMap (OSM) , SAR ve Fotogrametrik Sayısal Harita (FSH) verileri kullanıldı. İlk olarak, hem OSM verileri hem de SAR uydu görüntüsü üzerinde karakteristik ortak noktalar seçildi. $\mathrm{Bu}$ noktaların koordinatları QGIS yazılımı ile hesaplandı. Bu veri setlerindeki koordinat farklılıklarının normal dağılımı çizildi. Veri setlerinin normal dağılımda olduğu doğrulandı ve standart sapma değerleri hesaplandı. Maksimum ve minimum güven aralığı (\% 95) 2*standart sapma sınır değerlerine göre belirlendi. SAR \& OSM ve SAR \& FSH görüntü çiftlerinden seçilen 49 nokta için X ve Y koordinat farklılıkları hesaplandı. Son olarak, maksimum farklar, SAR konumsal doğruluğunun OSM ve FSH'ye göre 1 piksel azimut çözünürlüğünün altında olduğunu göstermektedir.
\end{abstract}

* Corresponding Author

*(fhorzum@akdeniz.edu.tr) ORCID ID 0000-0003-4898-5999

(nusretdemir@akdeniz.edu.tr) ORCID ID 0000-0002-8756-7127

(alikilcik@akdeniz.edu.tr) ORCID ID 0000-0002 -0094-1762 


\section{INTRODUCTION}

Synthetic Aperture Radar (SAR) images are used in applications for the Earth observation purposes since decades. SAR satellites carry an imaging sensor that can detect high-resolution ground images under a wide variety of imaging conditions (Demirci, 2005). To investigate the accuracy of the acquired SAR image from Sentinel-1 satellites, the Antalya is selected as test area.

The OpenStreetMap (OSM) and Photogrammetric Digital Map (PDM) data were used in comparison.

OSM is a common dataset used in many websites and mobile applications (Ünen, 2013). The accuracy (51.5\%) of OSM data in the Wuhan region of China were reported in Wang (2015). Çabuk et al., (2015) shows that 1: 50.000 scale OSM dataset is not enough to support the map production process.

PDM are used in public institutions and organizations and for the purpose of Geographical Information System (GIS). A study investigated (Kara 2019), the accuracy of Photogrammetric Digital Maps which contains the provincial borders of Erzincan and it has been reported that the horizontal coordinate average was calculated as $6 \mathrm{~cm}$ and the vertical coordinate average as $10 \mathrm{~cm}$.

S1A data products are already consistently providing highly accurate geolocation (Schubert 2015). Thus, we tried to explore the spatial accuracy of Sentinel 1 SAR data in respect to the available existing sources OSM and PDM.

In this study, characteristic common points were selected to compare the SAR and map data sets by 55 points for each data set. These points were chosen randomly from the, e.g. building and border corners and road junction points. The differences of the orthogonal coordinates of the raw data and the coordinates between the OSM and the SAR data and the PDM and the SAR data were calculated. It was identified that the data sets had normal distribution (Figure 2 \& Figure 3 ).

Standard deviation values were calculated in the second step in order to eliminate the outlier data points. Maximum and minimum confidence intervals (95\%) were selected with respect to the $2 *$ Standard deviation limit values. Then, erroneous data points were removed and 49 error-free data points were remained in each data set. Coordinate differences (Ya-Yc) of 49 common points in OSM and SAR data set; Coordinate differences (Yd-Yc) of (Xa-Xc) and 49 common points in PDM and SAR data set; (Xd-Xc) were calculated separately. The standard deviations of these coordinate differences were $11.646 \mathrm{~m}, 7.842 \mathrm{~m}$ and $10.520 \mathrm{~m}$ and $8.438 \mathrm{~m}$ respectively (Table $1 \& 2$ ). Coordinate difference graphs and location graphs of these data sets were drawn. Finally, as found in the comparison in these two data sets, it is shown that the SAR image data is have about $20 \mathrm{~m}$ accuracy.

\section{MATERIALS AND METHOD}

In this study, Antalya is selected as a test site as shown in Figure 1. The used datasets are Sentinel 1 SAR image, OSM and PDM which was provided by Municipality of Antalya.

Sentinel 1 has $C$ band RADAR sensor, operated by European Space Agency, and the respective data can be provided from Copernicus data hub. The $\mathrm{C}$ band has a frequency of $4-8 \mathrm{GHz}$ and a wavelength of $7.5-3.8 \mathrm{~cm}$. Over the past 30 years, SAR has been the most important data source in monitoring (Flores-Anderson et al. 2019). Therefore, it can penetrate into vegetation, dry soil and glaciers. The data have range and azimuth resolution 20x22 m respectively. They are provided with $10 \mathrm{~m}$ pixel spacing through Ground Range Detected (GRD) file format. GRD products consist of focused SAR data that has been detected, multi-looked and projected to ground range using an Earth ellipsoid model. There are three different GRD product resolution modes; Full Resolution (FR), High Resolution (HR) and Medium Resolution (MR). Product Resolutions by Mode: Strip Map (SM) GRD, Interferometric Wide Swath (IW) GRD and Extra Wide Swath (EW) GRD (URL-1). In this study, IW mode and HR resolution product were used.

OSM is an online geodatabase with OpenDataCommons license, which any person can contribute and update the datasets (Çabuk et al., 2015). OSM is a dataset service, created by a OSM Foundation that provide data about revery kind of features in the Earth. PDM dataset is produced by Antalya Municipality with $1 / 5000$ scale.

The accuracy of dataset is depending on the used data source (e.g. Satellite, mainly optical) and the digitizer accuracy.

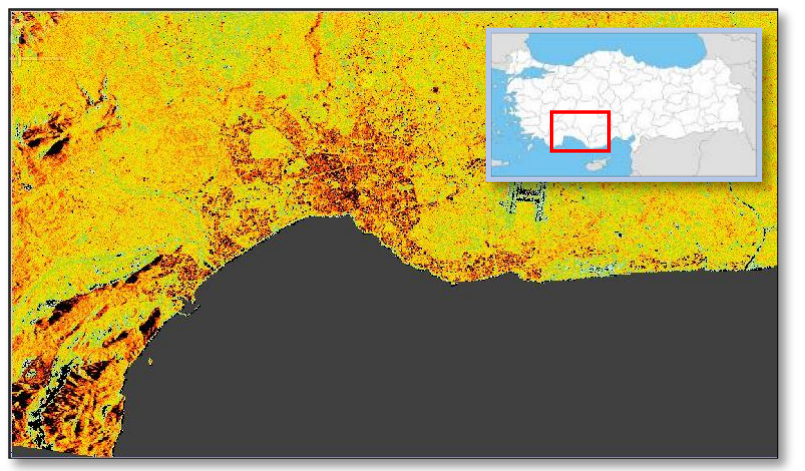

Figure 1. Map of study area which is produced by using Sentinel-1. In the small map selected total area are shown on the Turkey map

In this study, QGIS 3.12 and Sentinel Application Platform (SNAP 7.0) software were used to evaluate the data. The QGIS software was developed by the Open Source Geospatial Foundation (OSGeo) (URL-2). QGIS software is a multi-platform free and open source GIS software that provides data viewing, editing, and analysis capabilities. SNAP software was developed by 
the European Space Agency (ESA). SNAP software, on the other hand, is a common software and is developed for fast viewing, layer management, geocoding and correction using ground control points.

The Subset calibration, Speckle filtering and Geometric correction procedures were applied to the SAR Sentinel-1 Satellite data in the SNAP program. Calibration process has been applied. The objective of SAR calibration is to provide imagery in which the pixel values can be directly related to the radar backscatter of the scene. Filter operation "Lee" (3*3) filter is applied. WGS84 datum was used for geometric correction (Yommy et al., 2015 ; Smara et al., 2015)

55 data point were selected from OSM (a), Sentinel1 (c) and PDM (d) datasets. OSM (a), Sentinel-1 (c) and PDM(d) data of the study area were registered using the QGIS program.

Orthogonal Coordinates of 55 points were obtained with Python code software according to TUREF TM 30 reference information (URL-3).

\section{RESULTS}

In the first step, the coordinate differences of OSM and SAR data points (Ya-Yc) and (Xa-Xc) were calculated and the histograms of these coordinates were drawn (Figure $2 \& 3$ ).

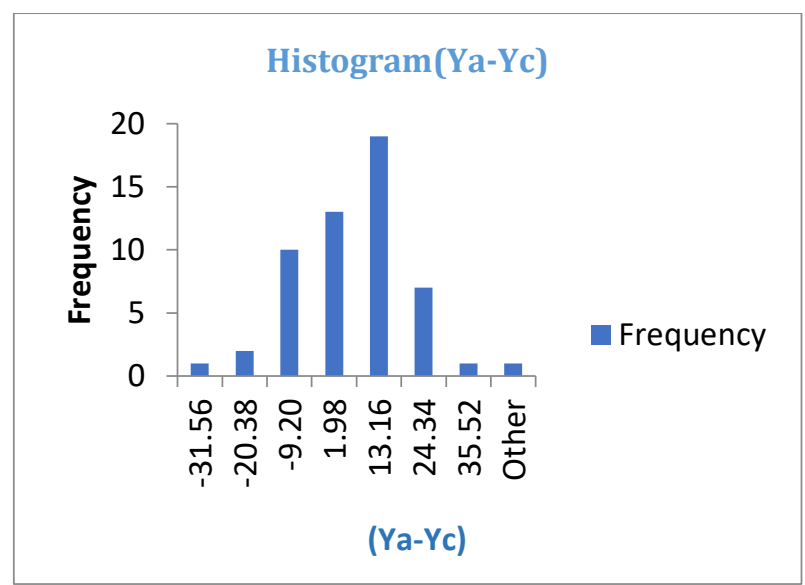

Figure 2. Histogram of Y Coordinate Differences (YaYc).

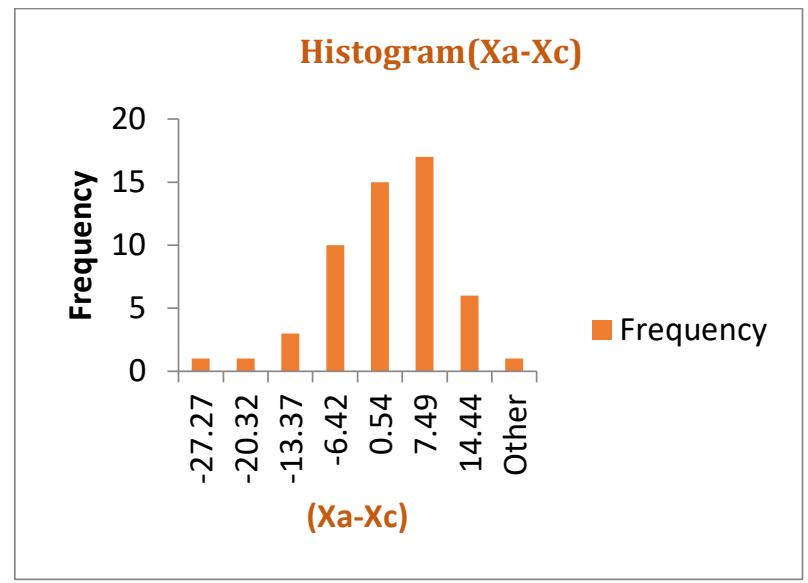

Figure 3. Histogram of X Coordinate Differences (Xa$\mathrm{Xc)}$.
In the second step, 55 points were used in comparison of SAR (c) and PDM (d) data. The coordinate differences (Yd - Yc and Xd - Xc) of these data points were calculated and histogram graphics were drawn (Figure 4 \& 5).

OSM (a), SAR (c) and PDM (d) data sets were determined to be in normal distribution.

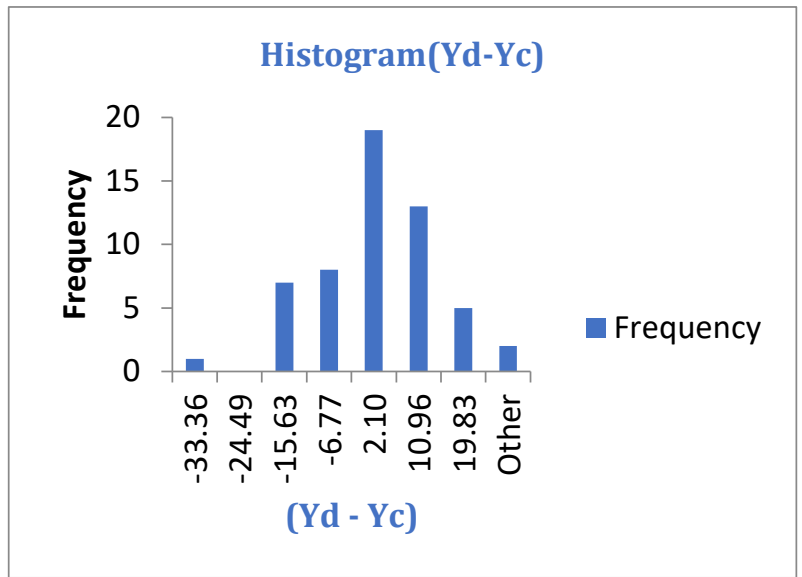

Figure 4. Histogram of Y Coordinate Differences (YdYc).

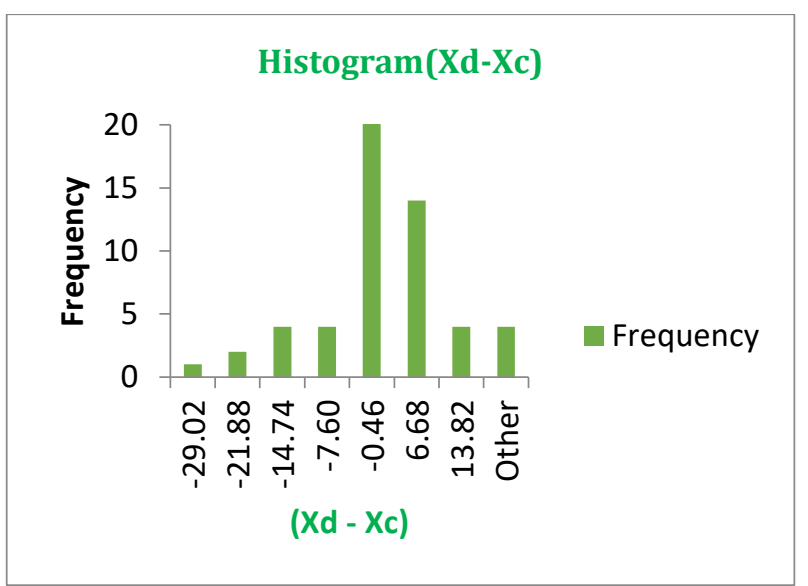

Figure 5. Histogram of $\mathrm{X}$ Coordinate Differences (Xd$\mathrm{Xc}$.

OSM (a) and SAR (c) data sets were determined to be normally distributed. The mean value of the (Ya - Yc) and (Xa - Xc) coordinate differences and standard deviation values were calculated. According to Equation 1; The minimum and maximum limit values of 2 standard deviations (95\%) were calculated and outliers were removed from the data sets. Thus, 49 compatible coordinates were found and the obtained results are presented in Table 1.

$(\bar{X}-2 \sigma) \leq \mu \leq(\bar{X}+2 \sigma)$

As seen in Table 1, the standard deviation is 11.646 $\mathrm{m}$ in the (Ya-Yc) differences and $7.842 \mathrm{~m}$ in the (Xa-Xc) differences. In addition, according to the $2 *$ Standard Deviation limit values, in (Ya-Yc) differences; in the range of $[-22.730 \mathrm{~m}$ to $23.855 \mathrm{~m}]$ and (Xa-Xc) differences; values have been reached in the range of [$17.216 \mathrm{~m}$ to $14.152 .86 \mathrm{~m}]$. 
Table 1. Computational summary of 49 compatible coordinates.

\begin{tabular}{lll}
\hline Calculation 1 & [Ya-Yc] $\mathbf{~ m}$ & [Xa-Xc] $\mathbf{~ m}$ \\
\hline Average & 0.563 & -1.532 \\
Std.Deviation & 11.646 & 7.842 \\
2*Std.Deviation & 23.293 & 15.684 \\
Minimum & -22.730 & -17.216 \\
Maximum & 23.855 & 14.152 \\
\hline
\end{tabular}

To obtain the error levels we used the percentage errors $\left([(\mathrm{Ya}-\mathrm{Yc}) / \mathrm{Ya}]^{*} 100\right.$ and $[(\mathrm{Xa}-\mathrm{Xc}) / \mathrm{Xa}]^{* 100)}$ of the difference values of the selected 49 points. We found that they vary between $[-0.004$ to +0.004$]$ and $[-0.001$ to $+0.001]$ for the above data sets, respectively.

According to Equation 2; (Ya-Yc) and (Xa-Xc) location values were calculated from the coordinate differences. Location graphs of 49 compatible points were drawn (Figure 6 \& 7).

$S_{a c}=\sqrt{(Y a-Y c)^{2}+(X a-X c)^{2}}$

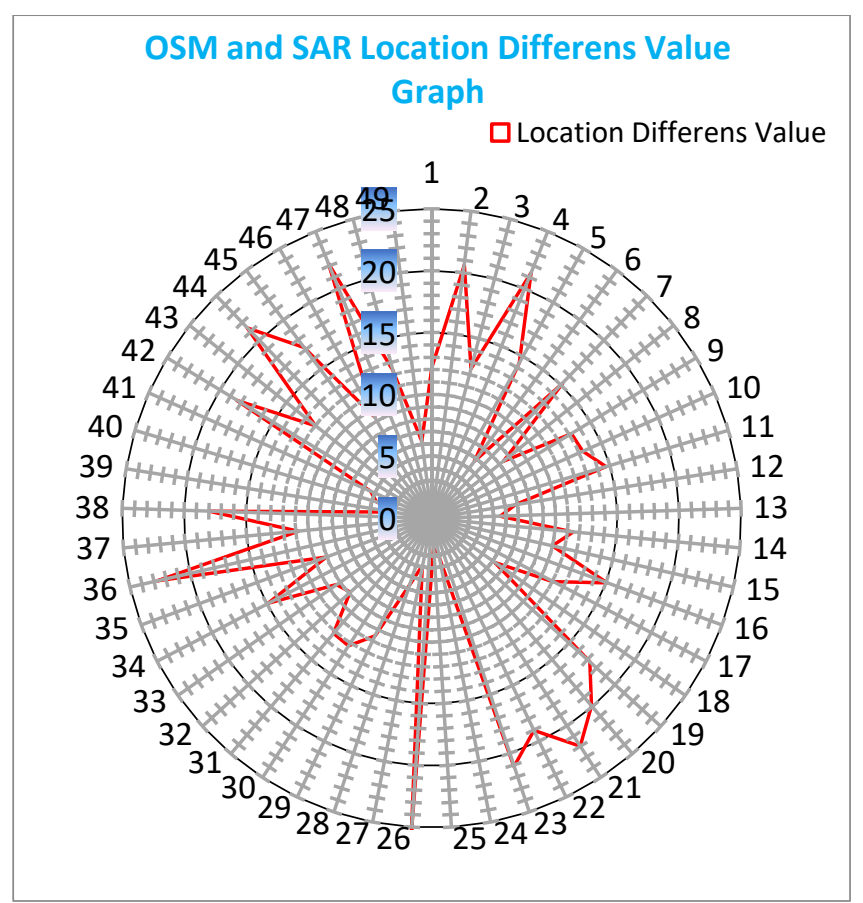

Figure 6. Location diffrences value graph between OSM and SAR data sets.

In figure 7 , the upward direction to the right is $\mathrm{Y}$ $(\mathrm{m})$ and the upward direction is $\mathrm{X}(\mathrm{m})$.

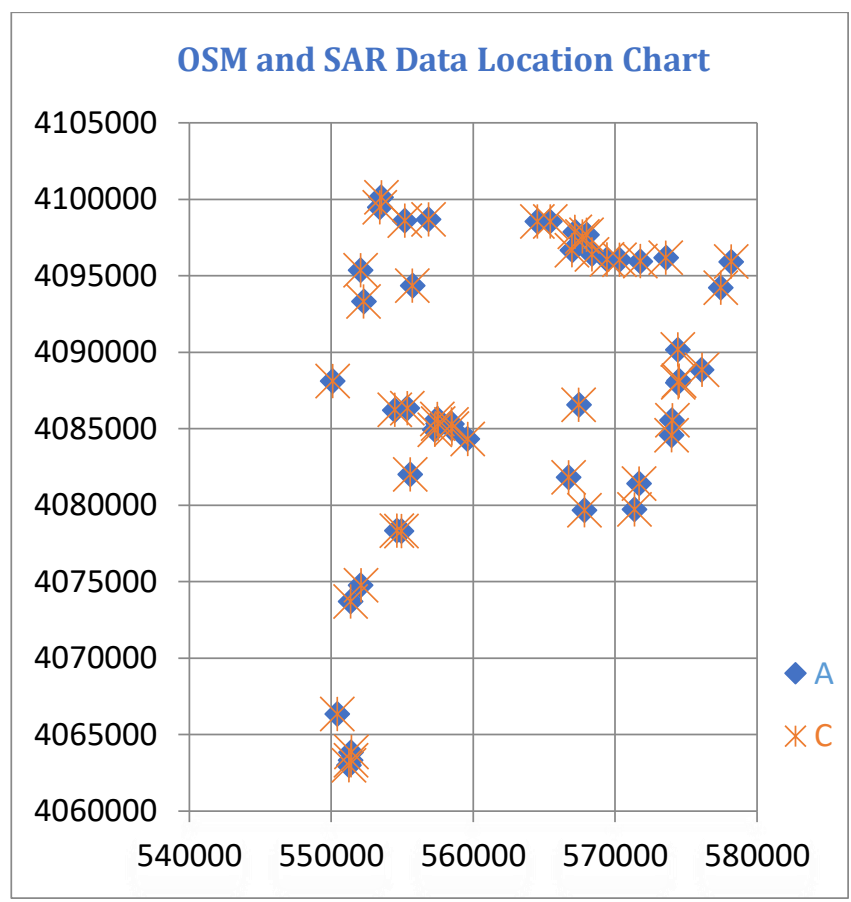

Figure 7. Coordinate plot of compatible points in $\operatorname{OSM}(\mathrm{a})$ and SAR(c)data.

It is shown that the PDM (d) and SAR (c) data set differences showed normal distribution. The average value of the (Yd-Yc) and $(\mathrm{Xd}-\mathrm{Xc})$ coordinate differences and standard deviation values were calculated. According to Equation 3; the minimum and maximum limit values of 2 standard deviations (95\%) were determined and 49 compatible coordinates were found. The results found are shown in table 2 .

$(\overline{\mathrm{X}}-2 \sigma) \leq \mu \leq(\overline{\mathrm{X}}+2 \sigma)$

As seen in Table 2, the standard deviation was $10.520 \mathrm{~m}$ in the (Yd-Yc) differences and $8.438 \mathrm{~m}$ in (Xd-Xc) differences. In addition, according to the $2 *$ Standard Deviation limit values, in (Yd-Yc) differences; in the range of [-22.044 $\mathrm{m}$ to $20.035 \mathrm{~m}$ ] and (Xd-Xc) differences; values in the range of [-18.298 $\mathrm{m}$ to 15.452 $\mathrm{m}]$ have been reached.

Table 2. Computational summary of 49 compatible coordinates.

\begin{tabular}{lll}
\hline Calculation 2 & [Yd-Yc] $\mathbf{~ m}$ & [Xd-Xc] $\mathbf{~ m}$ \\
\hline Average & -1.004 & -1.423 \\
Std.Deviation & 10.520 & 8.438 \\
2*Std.Deviation & 21.040 & 16.875 \\
Minimum & -22.044 & -18.298 \\
Maximum & 20.035 & 15.452 \\
\hline
\end{tabular}

We also calculated the percentage error of the difference values of selected 49 points and found that it varies between $[-0.004$ to +0.004$]$ and $[-0.001$ to $+0.001]$, respectively.

According to Equation 4; (Yd-Yc) and (Xd-Xc) location value was calculated from the coordinate differences. Location graphs of 49 compatible points were drawn (Figure 8 \& 9).

$S_{d c}=\sqrt{(Y d-Y c)^{2}+(X d-X c)^{2}}$ 


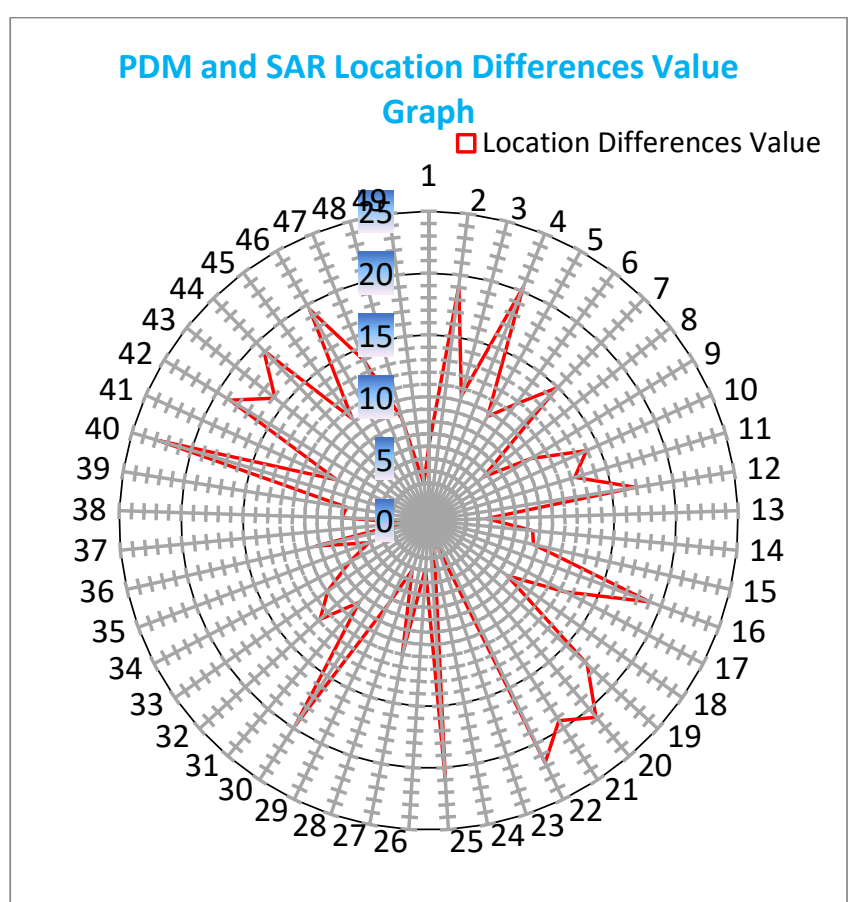

Figure 8. Location differences value graph between PDM and SAR data.

In figure 9 and 10, the upward direction to the right is $\mathrm{Y}(\mathrm{m})$ and the upward direction is $\mathrm{X}(\mathrm{m})$.

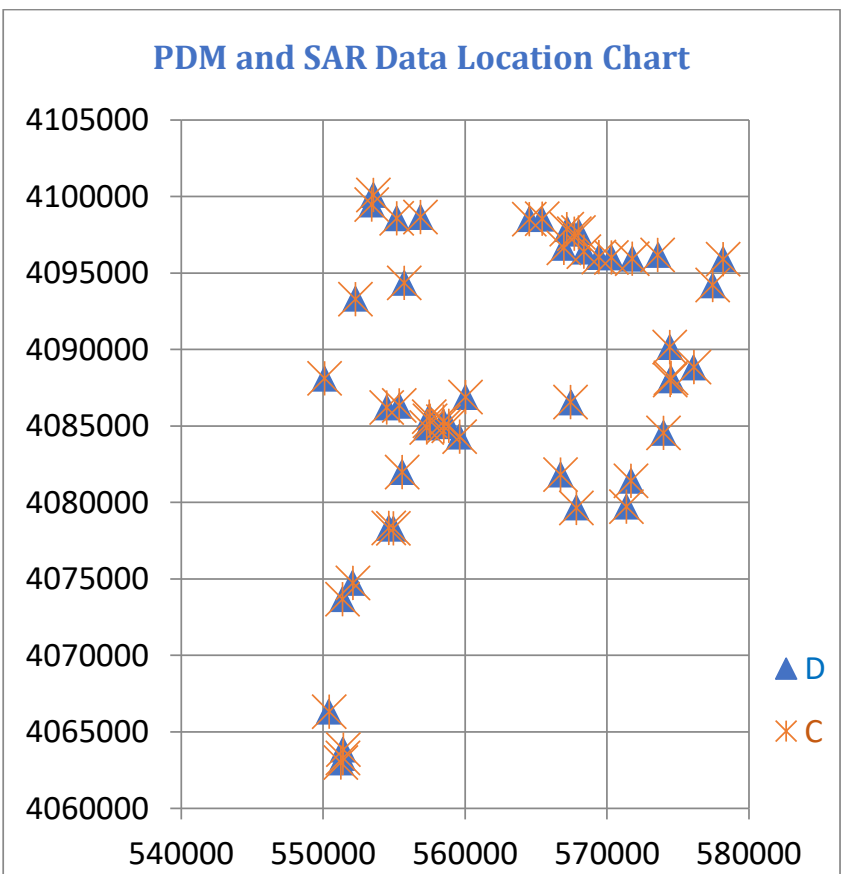

Figure 9. Coordinate plot of compatible points in $\operatorname{PDM}(\mathrm{D})$ and SAR(C) data.

Finally, a graph shows the coordinate difference values of the data sets (Ya-Yc, Xa-Xc and Yd-Yc, Xd-Xc) both. From this chart (Figure 10), it was observed that $95 \%$ of the coordinate differences were within the \pm 25 $\mathrm{m}$ radius circle. $53.1 \%$, of the (Yd-Yc) and (Xd-Xc) coordinate differences (blue points) are located within the $\pm 10 \mathrm{~m}$ circle, while $36.7 \%$, of the (Ya-Yc) and (Xa-Xc) coordinate differences (orange points) are located within the $\pm 10 \mathrm{~m}$ circle. Thus, we may conclude that the OSM data fit SAR data better than PDM data.

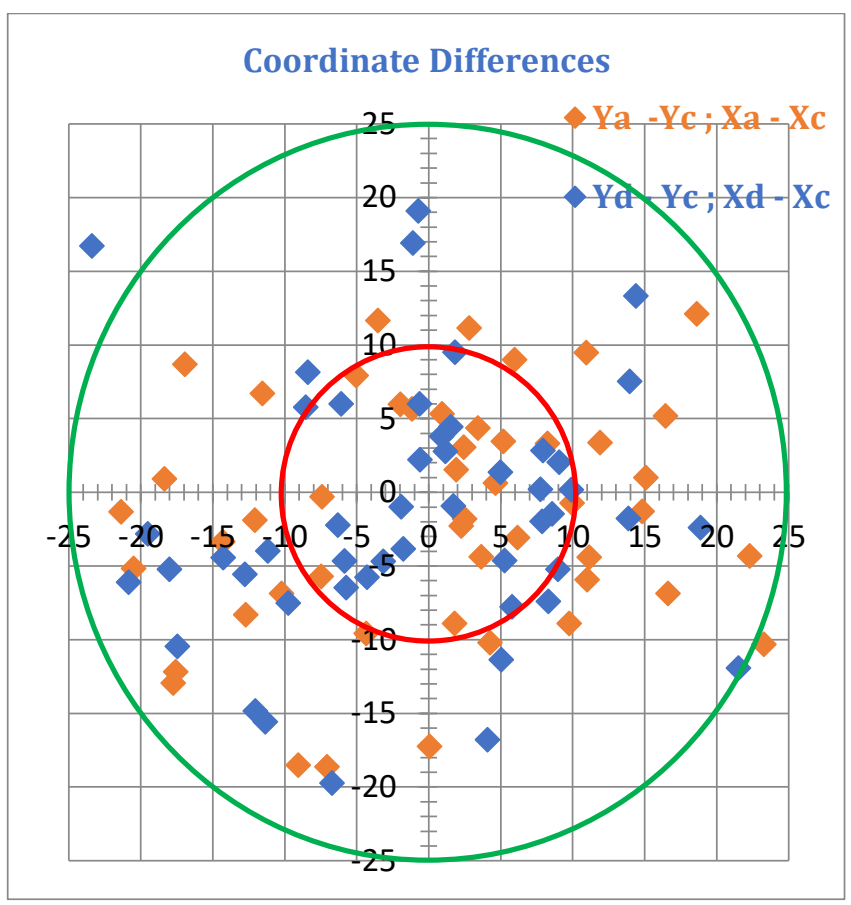

Figure 10. Location graph created according to OSM, PDM and SAR coordinate differences.

\section{CONCLUSIONS}

In the study of the spatial accuracy of Sentinel-1 SAR satellite images, OSM and PDM data were used for comparison. OSM and PDM data sets were used as accurate data and SAR satellite data as experimental data set.

55 points were used to compare $\operatorname{OSM}(\mathrm{a}), \operatorname{SAR}(\mathrm{c})$ and PDM(d) data sets. 6 points of data were excluded from each data set because they were incompatible. Coordinate differences were calculated with 49 points in the comparison of the data sets without error on OSM (a), SAR(c) and PDM(d). Average and standard deviation values were calculated. The minimum and maximum values were determined according to the value of $2 *$ standard deviation (95\%).

It was observed that the coordinate differences (Yd-Yc) and (Xd-Xc) were represented better than the coordinate differences (Ya-Yc) and $(\mathrm{Xa}-\mathrm{Xc})$ within the $\pm 10 \mathrm{~m}$ radius circle.

As a result, it is concluded that SAR data with a maximum difference with $20 \mathrm{~m}$ well fit with OSM and PDM data sets. SAR data show better agreement with OSM data compared to PDM data for the $\pm 10 \mathrm{~m}$ difference. It can be concluded that OSM and PDM datasets can be directly used with Sentinel 1 datasets without need of intensive co-registration for any further analysis.

\section{ACKNOWLEDGEMENT}

We, authors acknowledge Antalya Metropolitan Municipality for the Photogrammetric Digital Map data. 


\section{REFERENCES}

Çabuk, S., Erdoğan, M., Eker, O., Kaya, M,, Ardıç, H. \& Önal, E. (2015) Use of OpenStreetMap Data In Topographic Data Production. TUFUAB VIII. Technical Symposium, 21-23 May 2015 / Konya

Çabuk. S., Erdoğan, M. \& Önal, E. (2015) Researching of 1/50K Scaled Map Producibility Using Open Street Map Data. Map Journal, 2015(154).

Demirci Ş. (2005) Elimination of Unwanted Echoes in Sentinel Aperture Radar (SAR) Images. Post Graduate thesis, Mersin University, Mersin, 86s.

Flores-Anderson, A. I., Herndon, K. E, Thapa, R. B. \& Cherrington, E. (2019) The SAR Handbook: Comprehensive Methodologies for Forest Monitoring and Biomass Estimation. First edition. Published electronically April 2019. doi: $10.25966 / \mathrm{nr} 2 \mathrm{c}-\mathrm{s} 697$.

Kara, G. \& Kemaldere, H. (2019). Accuracy Analysis of Photogrammetric Digital Topographic Mapping, TMMOB Chamber of Survey and Cadastre Engineers, 17th Turkey Scientific and Technical Conference, 25-27 April 2019 in Ankara.

Schubert, A. Small, D. Miranda, N. Geudtner, D. \& Meier, E.(2015). Sentinel-1A Product Geolocation Accuracy: Commissioning Phase Results. Remote Sensing. 7. 9431-9449. 10.3390/rs70709431.

Smara, Y., Boutarfa, S. \& Bouchemakh, L. (2015) Comparative Study of Speckle Filtering Methods in Polsar Radar. IEEE Xplore.
Ünen, H. C., Yılmaz, O. M. \& Güngör. O. (2013). Free Map: OpenStreetMap. TMMOB Geographical Information System Congress, 11-13 November 2013, Ankara

Wang M, Li Q,Hu Q \& Zhou M. (2013) Qualıty Analysis of Open Street Map Data. International Archives of the Photogrammetry, Remote Sensing and Spatial Information Sciences, Volume XL-2/W1, 2013 8th International Symposium on Spatial Data Quality, 30 May - 1 June 2013, Hong Kong

Yommy, A. S., Liu, R. \& Wu, S. (2015) SAR Image Despeckling using Refined Lee Filter. 2015 7th International Conference on Intelligent HumanMachine Systems and Cybernetics,

\section{Internet address}

URL-1: https://sentinel.esa.int/web/sentinel/technicalguides/sentinel-1-sar/products-algorithms/level1-algorithms/ground-range-detected [access date: 15.02.2021]

URL-2: https://www.osgeo.org/ [access date: 15.02.2021]

URL-3: https://tucbs-public-api.csb.gov.tr/tucbs/ tucbs_tanimlama_dokumanlari/TUCBS_CG.pdf [access date: 15.02.2021] 